\title{
Smoking-induced aggravation of experimental arthritis is dependent of aryl hydrocarbon receptor activation in Th17 cells
}

Jhimmy Talbot ${ }^{1}$, Raphael S. Peres ${ }^{2}$, Larissa G. Pinto ${ }^{1}$, Rene D. R. Oliveira ${ }^{3}$, Kalil A. Lima², Paula B. Donate ${ }^{1}$, Jaqueline R. Silva², Bernard Ryffel ${ }^{4,5}$, Thiago M. Cunha' ${ }^{1}$, José C. Alves-Filho ${ }^{1}$, Foo Y. Liew ${ }^{6,7^{*}}$,

Paulo Louzada-Junior ${ }^{3^{*}}$ and Fernando de Queiroz Cunha ${ }^{1 *}$

\begin{abstract}
Background: Epidemiologic studies have highlighted the association of environmental factors with the development and progression of autoimmune and chronic inflammatory diseases. Among the environmental factors, smoking has been associated with increased susceptibility and poor prognosis in rheumatoid arthritis (RA). However, the immune and molecular mechanism of smoking-induced arthritis aggravation remains unclear. The transcription factor aryl hydrocarbon receptor (AHR) regulates the generation of Th17 cells, CD4 T cells linked the development of autoimmune diseases. AHR is activated by organic compounds including polycyclic aromatic hydrocarbons (PAHs), which are environmental pollutants that are also present in cigarette smoke. In this study, we investigated the role of AHR activation in the aggravation of experiment arthritis induced by exposure to cigarette smoke.

Methods: Mice were exposed to cigarette smoke during the developmental phase of antigen-induced arthritis and collagen-induced arthritis to evaluate the effects of smoking on disease development. Aggravation of articular inflammation was assessed by measuring neutrophil migration to the joints, increase in articular hyperalgesia and changes in the frequencies of Th17 cells. In vitro studies were performed to evaluate the direct effects of cigarette smoke and PAH on Th17 differentiation. We also used mice genetically deficient for AHR (Ahr KO) and IL-17Ra (II17ra $\mathrm{KO}$ ) to determine the in vivo mechanism of smoking-induced arthritis aggravation.
\end{abstract}

Results: We found that smoking induces arthritis aggravation and increase in the frequencies of Th17 cells. The absence of IL-17 signaling (II17ra KO) conferred protection to smoking-induced arthritis aggravation. Moreover, in vitro experiments showed that cigarette smoke can directly increase Th17 differentiation of T cells by inducing AHR activation. Indeed, Ahr KO mice were protected from cigarette smoke-induced arthritis aggravation and did not display increase in TH17 frequencies, suggesting that AHR activation is an important mechanism for cigarette smoke effects on arthritis. Finally, we demonstrate that PAHs are also able to induce arthritis aggravation.

(Continued on next page)

\footnotetext{
*Correspondence: foo.liew@glasgow.ac.uk; plouzada@fmrp.usp.br; fdqcunha@fmrp.usp.br

${ }^{6}$ Division of Immunology, Infection and Inflammation, Glasgow Biomedical Research Centre, University of Glasgow, Glasgow G12 8TA, UK

${ }^{3}$ Division of Clinical Immunology, Ribeirao Preto Medical School, University of São Paulo, Ribeirao Preto, Brazil

'Department of Pharmacology, Ribeirao Preto Medical School, University of

Sao Paulo, Av. Bandeirantes, 3900, Ribeirao Preto, SP 14049900, Brazil

Full list of author information is available at the end of the article
}

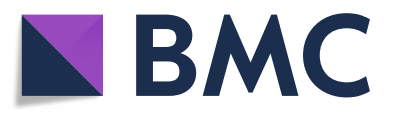

(c) The Author(s). 2018 Open Access This article is distributed under the terms of the Creative Commons Attribution 4.0 International License (http://creativecommons.org/licenses/by/4.0/), which permits unrestricted use, distribution, and reproduction in any medium, provided you give appropriate credit to the original author(s) and the source, provide a link to the Creative Commons license, and indicate if changes were made. The Creative Commons Public Domain Dedication waiver (http://creativecommons.org/publicdomain/zero/1.0/) applies to the data made available in this article, unless otherwise stated. 
(Continued from previous page)

Conclusions: Our data demonstrate that the disease-exacerbating effects of cigarette smoking are AHR dependent and environmental pollutants with AHR agonist activity can induce arthritis aggravation by directly enhancing Th17 cell development.

Keywords: Rheumatoid arthritis, Cigarette smoke, Inflammation, Polycyclic aromatic hydrocarbons, Th17

\section{Background}

Smoking is the major known environmental risk factor associated with the development of rheumatoid arthritis (RA) $[1,2]$. Epidemiologic studies show that current and previous smoking is correlated not only with increased risk to RA development, but also to increased disease severity and reduced responsiveness to therapy [3]. Heavy smokers have twice the chance of developing RA than non-smokers [4] and an increased risk for radiographic progression [5]. Several molecular mechanisms for the increase in arthritis severity have been proposed, such as the increase in oxidative stress $[6,7]$, induction of enzymes that increase protein citrullination [8-11], and nicotine activation of $\alpha 7$-nicotinic acetylcholine receptors in neutrophils [12]. However, little is known about the molecular mechanism by which smoking affects the adaptive immune response on arthritis. Indeed, despite its pro-inflammatory effects on neutrophils [12], nicotine has an immunosuppressive effect on the immune system, suggesting that other components of cigarette smoke might be related to modulation of disease severity [13].

Among the cells for adaptive immunity, a population of interleukin 17 (IL-17)-producing $\mathrm{CD}^{+}{ }^{+} \mathrm{T}$ cells (Th17) has been implicated as a key player in RA development and progression [14, 15]. Differentiation of Th17 cells follows a complex transcriptional regulatory network dependent on the nuclear receptor RORyt and its collaboration with other transcription factors [16]. Recent reports suggest that the transcription factor aryl hydrocarbon receptor (AHR) plays an important role in the regulation of Th17 cells development. Activation of AHR increases Th17 differentiation in vitro and $A h r$ genetic-deficient mice develop less severe collagen-induced arthritis via modulation of Th17 [17-19]. AHR, a member of the basic helix-loophelix Per-Arnt-Sim (bHLH-PAS) superfamily, is a liganddependent transcription factor also known as 'pollutant receptor'. This receptor is activated by a variety of organic compounds including polycyclic aromatic hydrocarbons (PAH) [20]. These are persistent organic environmental pollutants, which are present in cigarette smoke [21, 22]. We hypothesized that AHR activation by cigarette smoke components could be responsible for the aggravation of arthritis.

To understand how smoking modulates the immune response and disease aggravation, we developed a murine model of cigarette smoke exposure during antigeninduced articular disease development. Using this model, we identified that smoking-induced arthritis aggravation is dependent on AHR activation in T cells, Th17 expansion, and interleukin 17 receptor A (IL-17RA) signaling, showing a strong link between this pollutant receptor and arthritis progression. Our results suggest that AHR activation in Th17 cells might be a convergent mechanism by which different environmental pollutants aggravate autoimmune diseases.

\section{Methods \\ Chemicals and reagents}

The following materials were used: AHR agonist FICZ (6-formylindolo[3,2-b]carbazole, BIOMOL, Plymouth Meeting, PA, USA,); AHR antagonist CH223191 (1-Methyl-N-[2-methyl-4-[2-(2-methylphenyl)diazenyl]phenyl$1 \mathrm{H}$-pyrazole-5-carboxamide, Tocris Bioscience, Ellisville, MO, USA); anti-CD3 and anti-CD28 (eBioscience, San Diego, CA, USA) benzo[b]fluoranthen, phorbol-12myristate-13-acetate (PMA), ionomycin, methylated bovine serum albumin (mBSA), complete Freund's adjuvant (CFA)with $1 \mathrm{mg} / \mathrm{ml}$ of Mycobacterium tuberculosis and RPMI 1640 medium (all from Sigma-Aldrich, St. Louis, MO, USA), $\alpha$-IL-17a (eBioscience, anti-mouse IL17A functional grade purified, Clone: eBioMM17F3).

\section{Mice}

C57BL/6 wild-type (WT), DBA1/J and Il17 receptor genetic-deficient mice on the C57BL/6 background $\left(I l 17 \mathrm{ra}^{-/-}\right)$[23] were bred in a specific pathogen-free animal facility at the School of Medicine of Ribeirao Preto, University of São Paulo. $A h r^{-1-}$ mice [24] on the C57BL/6 background and their corresponding WT mice were bred in a specific pathogen-free animal facility at the Immunologie et Neurogenetique Experimentales et Moleculaires, Orleans, France (Centre National de la Recherche Scientifique, Orleans, France). Naïve male mice (6- to 12-weeks old) were maintained in sterile, isolated, ventilated cages with controlled temperature, light conditions and ad libitum access to food and water. All the genetic-deficient mice (Il17ra ${ }^{-/-}$and $\mathrm{Ahr}^{-/-}$) displayed overall good health conditions and optimal breeding. Animal husbandry and procedures were in accordance with the guidelines of the Animal Ethics 
Committee of the School of Medicine of Ribeirao Preto, University of São Paulo (number 038/2009).

\section{Induction of experimental arthritis Antigen-induced arthritis (AIA)}

Mice were anesthetized with $2 \%$ isoflurane before immunization and challenge. Mice were injected subcutaneously (s.c.) on day 0 with $500 \mu \mathrm{g}$ of mBSA in 0 . $2 \mathrm{ml}$ of an emulsion containing $0.1 \mathrm{ml}$ saline and $0.1 \mathrm{ml}$ CFA, and boosted on day 7 and 14 with the same preparation in incomplete Freund's adjuvant (IFA). Shamimmunized mice were given similar injections without mBSA. On day 21 after the first immunization, mice were challenged by intra-articular (i.a.) injection of mBSA $(10 \mu \mathrm{g}$ in $10 \mu \mathrm{l}$ of PBS) into the right knee joint using a sterile 33-gauge syringe. Control mice were injected with $10 \mu \mathrm{l}$ of PBS alone. Mechanical articular hyperalgesia and neutrophil infiltration were evaluated $7 \mathrm{~h}$ after challenge on day 21 after first immunization. For evaluation of Th17 cell frequencies draining lymph nodes (DLNs) were collected 18 days after first immunization and analyzed by flow cytometry. For histologic analysis of the knee joints, mice were challenged 7 days after first mBSA injection and euthanized 7 days later to excise the femur-tibial joints. Mice were treated with FICZ $(90 \mu \mathrm{g} / \mathrm{kg}$, i.p.) or vehicle [dimethyl sulfoxide (DMSO) 1\% in PBS] twice (on days 12 and 17 after first immunization). We selected the in vivo dose of FICZ based in a pilot dose-response curve experiment $(10,30$ and $90 \mu \mathrm{g} / \mathrm{kg}$ ) with showed that $90 \mu \mathrm{g} / \mathrm{kg}$ induces the higher increase disease aggravation (data not shown).

\section{Collagen-induced arthritis (CIA) [25]}

Male DBA/1 J mice (10 weeks old) were injected intradermally (i.d.) on day 0 at the base of the tail with $200 \mu \mathrm{g}$ of bovine type II collagen (CII, a gift of Dr. David D. Brand, University of Tennessee Health Science Center) emulsified in CFA. Mice were boosted i.d. with CII (200 $\mu \mathrm{g}$ emulsified in IFA) on day 21 and monitored daily for signs of arthritis. Scores were assigned based on erythema, swelling, or ankylosis present in each paw on a scale of 0 to 3, giving a maximum score of 12 per mouse. Mice were treated with FICZ $(90 \mu \mathrm{g} / \mathrm{kg}$, i.p.) or vehicle (DMSO 1\% in PBS) twice (on days 12 and 17 after first immunization). All mice were euthanized on day 31 for evaluation of neutrophil infiltration in the femur-tibial joints [by myeloperoxidase (MPO) activity] and measurement of cytokines in the paws.

\section{Pharmacologic and immunobiologic protocols}

For AHR blockage experiments mice were treated with an AHR antagonist, $\mathrm{CH} 223191$ (2.5 mg/kg, i.p.), every day from 11 to 19 day after first immunization. For neutralization of IL-17 activity during AIA development, mice were treated (i.p.) with an anti-mouse/rat IL-17A antibody, $5 \mathrm{mg} / \mathrm{kg}$, daily, from 12 to 17 days after first immunization.

\section{Cigarette smoke exposure}

Mice were exposed to smoke from commercial filtertipped cigarettes (Marlboro 100s, Phillip Morris, yielding $0.8 \mathrm{mg}$ nicotine and $10 \mathrm{mg}$ tar per cigarette) in a smoking chamber modified from that of Sham [26]. Mice were exposed to one, two or three cigarettes per day (4. 5 min per cigarette, five animals/chamber) twice on days 12 and 17 after first immunization. Smoke exposure was carried out by intermittently forcing air $(2.5 \mathrm{l} / \mathrm{min})$ through a burning cigarette. The intermittent cycles of forcing clean air were performed to mimic human smokers' puff cycles and to prevent $\mathrm{CO}_{2}$-induced asphyxiation. Smoke cycles consisted of $15 \mathrm{~s}$ of active cigarette smoke followed by $30 \mathrm{~s}$ of forced clean air controlled by a two-way valve timer. For smoking $>1$ cigarette per day, mice were rested for $3 \mathrm{~h}$ between each cigarette.

\section{Cigarette smoke-conditioned medium}

The cigarette smoke-conditioned medium was prepared as follows: smoke from two filtered cigarettes (Marlboro 100s, Phillip Morris) was bubbled through $10 \mathrm{ml}$ serumfree RPMI-1640 medium with a mechanical vacuum pump. The extract was filtered through a $0.22 \mu \mathrm{m}$ filter (Millipore, Bedford, MA, USA) to remove bacteria and particles and diluted to a final volume of $400 \mathrm{ml}$ with RPMI medium (five cigarettes/L). RPMI was chosen for these experiments since it has a low intrinsic AhR activity, reducing the background for the assay of AhR activation and consequently increasing the noise-to-signal ratio. Finally, CS-conditioned medium was incubated for $90 \mathrm{~min}$ at $37{ }^{\circ} \mathrm{C}$, in room air. The $\mathrm{pH}$ of conditioned medium was not different from that of untreated RPMI. To standardize the concentration, AHR activity was evaluated by a luciferase assay. In most experiments (except described otherwise in the legends) CS-conditioned medium was used at five cigarettes per liter.

\section{Adoptive transfer of $\mathrm{CD}^{+}{ }^{+} \mathrm{T}$ cells}

$\mathrm{CD}^{+} \mathrm{T}$ cells (>95\% pure) were obtained from WT C57BL/6 mice by negative selection (Miltenyi Biotec, Bergisch Gladbach, Germany) and injected intravenously $\left(5 \times 10^{6}\right.$ cells) into naïve $A h r^{-/-}$mice, which were then immunized 1 day later by the AIA protocol described above. 


\section{Determination of articular hyperalgesia}

Articular hyperalgesia of the femur-tibial joint was determined as previously described [27]. In a quiet room, mice were placed in acrylic cages $(12 \times 10 \times 17 \mathrm{~cm}$ high) with a wire grid floor, 15-30 min before testing for environmental adaptation. Stimulations were performed only when animals were quiet, did not display exploratory movements or defecation, and were not resting on their paws. An electronic pressure-meter consists of a hand-held force transducer fitted with a polypropylene tip $\left(4.15 \mathrm{~mm}^{2}\right)$ (IITC Inc., Life Science Instruments, Columbia, MD, USA) was used. An increasing perpendicular force was applied to the central area of the plantar surface of the hind paw to induce flexion of the femur-tibial joint followed by paw withdrawal. The pressure of force applied when the paw was withdrawn was recorded by the pressure meter. The test was performed by investigators blinded to the treatment and repeated until three consistent consecutive measurements (variation $<1 \mathrm{~g}$ ) were obtained. Mechanical threshold is expressed in grams ( $\mathrm{g}$ ) and hyperalgesia is equated to reduction of this threshold.

\section{Assay for joint neutrophil infiltration}

Seven hours after mBSA or PBS challenge AIA mice were euthanized and articular cavities washed twice with $10 \mu \mathrm{l}$ PBS containing $1 \mathrm{mM}$ EDTA and then diluted to a final volume of $50 \mu \mathrm{l}$ with PBS/EDTA. Total number of leukocytes was determined in a Neubauer chamber diluted in Turk's solution. Differential cell counts were determined in cytocentrifuged Rosenfeld stained slices (Shandon Cytospin 4, Thermo Fisher Scientific, Waltham, MA, USA) with a light microscope. Results are expressed as the number (mean \pm SEM) of neutrophils per cavity.

\section{Cytokine measurement in $\mathrm{CIA}$ mice}

IL-17 cytokines were measured by ELISA from homogenates of the mouse hind paws using paired antibodies (R\&D Systems, Minneapolis, MN, USA).

\section{Determination of neutrophil accumulation in $\mathrm{ClA}$}

MPO activity was used as an index of neutrophil accumulation in the mouse plantar tissues and was based on a kinetic-colorimetric assay, as previously described [28].

\section{mRNA expression in DLNs}

Inguinal DLNs were harvested 7 days after first immunization. Total RNA was extracted using TRIzol (Invitrogen, Waltham, MA, USA) following manufacturer's instructions. Total RNA was reverse-transcribed to cDNA with oligo d(T)16 primers (Applied Biosystems, Foster City, CA, USA). cDNA was used as template for qPCR of genes of interest (SYBR green method) using
ViiA7 System (Applied Biosystems). mRNA expression was analyzed using the following primers/probes $(0.5$ $\mu \mathrm{M})$ : Il17, F-CTCCAGAAGGCCCTCAGACTAC / RGGGTCTTCATTGCGGTGG; Gapdh, F-GGGTGTGAA CCACGAGAAAT / R-CCTTCCACAATGCCAAAGTT; $A h r, \quad$ F-CAAATCAGAGACTGGCAGGA / R-AGAA GACCAAGGCATCTGCT; Cyp1a1, F-GTTCTTGGAGC TTCCCCGAT / R-CTGACACGAAGGCTGGAAGT.

\section{Cell sorting and in vitro Th17 cell differentiation}

$\mathrm{CD}^{+} \mathrm{T}$ cells were purified from spleen and lymph nodes of C57BL/6 mice using anti-CD4 microbeads (Miltenyi Biotech) and then stained in PBS with 2\% FCS for $15 \mathrm{~min}$ at room temperature with anti-CD4-FITC and anti-CD62L-PercP (both Biolegend, San Diego, CA, USA). The naive $\mathrm{CD} 4^{+} \mathrm{CD} 62 \mathrm{~L}^{\text {high }} \mathrm{T}$ cells were sorted using the BD FACSAria II cell sorter. After sorting, cells were activated for Th17 differentiation with anti-CD3 (2 $\mu \mathrm{g} / \mathrm{ml}$, plate-bound), anti-CD28 $(2 \mu \mathrm{g} / \mathrm{ml}$, soluble), rhTGF- $\beta 1$ (2.5 ng/ml, Miltenyi Biotec), and rmIL-6 $(20 \mathrm{ng} / \mathrm{ml}$, Miltenyi Biotec). Cells were cultured for $72 \mathrm{~h}$ and analyzed by FACS.

\section{Flow cytometry and intracellular cytokine staining}

Cells from DLNs or in vitro differentiated $\mathrm{T}$ cells were stimulated for $4 \mathrm{~h}$ with phorbol 12-myristate 13-aceate (PMA) $(50 \mathrm{ng} / \mathrm{ml})$, ionomycin $(500 \mathrm{ng} / \mathrm{ml})$ and a protein transport inhibitor containing monensin (BD Biosciences, Franklin Lakes, NJ, USA) before detection by staining with antibodies. Surface markers (anti-CD3 and anti-CD4) were stained in PBS with $2 \%$ FCS for $10 \mathrm{~min}$ at room temperature, then fixed in Cytoperm/Cytofix (BD Biosciences), permeabilized with Perm/Wash Buffer (BD Biosciences) and stained with allophycocyanin antimouse interferon gamma (IFN- $\gamma$ ) and phycoerythrin anti-IL-17A (both BD Bioscience). Cells were assayed by FACS Canto or FACS Verse (both BD Biosciences) and analyzed using Flow Jo software (Treestar, Ashland, OR, USA).

\section{Luciferase assay to detect AHR agonist activity}

Mammalian cell line (Hepa1-6) stably transfected with a vector, pGL4.43 [luc2P/XRE/Hygro], containing a xenobiotic responsive elements (XRE) that drives transcription of the luciferase reporter geneluc2P (Photinuspyralis) was used. The vector contains a hygromycin resistance gene to allow selection of stably transfected cell. For the luciferase induction studies, cells were grown in 48-well plates $(5 \times$ $10^{5}$ cells/well) and incubated for $12 \mathrm{~h}$ with FICZ (300 nM) , cigarette smoke-enriched medium (CSEM) or the AHR ligands benzo[b]fluoranthen. Luciferase activity in cell lysates was determined in a reaction with luciferin using a microplate luminometer. Values are presented 
as the mean $\pm \mathrm{SD}$ and are expressed as relative luminescence units.

\section{Statistical analysis}

Where appropriate (described in legends) data analysis was performed using two-way analysis of variance (ANOVA), unpaired two-tailed Student's $t$ test. Data are expressed as means \pm SEM and are representative of two to three independent experiments. Means from different treatments assessed in one time point were compared by one-way ANOVA with Bonferroni's correction. All statistical analyses were performed with the GraphPad Prism software 5.00 (GraphPad Software, San Diego, CA, USA). $P<0.05$ was considered statistically significant.

\section{Results}

Smoking induces aggravation of arthritis in an IL-17RAdependent manner

We developed a murine model of smoking exposure during arthritis development to evaluate the mechanisms by which environment pollutants might induce aggravation of autoimmune diseases. C57BL/6 mice were exposed to cigarette smoke during the immunization phase of AIA. Exposure to cigarette smoke induced a dose-dependent increase in mechanical articular hyperalgesia and neutrophil infiltration into the joints (Fig. 1a). In the model of CIA, exposure to cigarette smoke also exacerbated disease incidence, arthritis scores and neutrophil infiltration into the joints (Fig. 1b). We observed a cigarette dose-dependent increase in the expression of Il17 mRNA in the DLNs of mice during AIA development (Fig. 1c). The frequencies of Th17 cells were also higher in the DLNs of mice exposed to cigarette smoke than control mice (Fig. 1d). Importantly, smoking-induced arthritis aggravation, determined by neutrophil infiltration in the joints and mechanical articular hyperalgesia in the AIA model, was absent in mice genetically deficient of IL17RA $\left(I l 17 \mathrm{ra}^{-/}\right)$(Fig. 1e). These results indicate that cigarette smoking-induced aggravation of articular inflammation is associated with an increase of Th17 frequencies and dependent on IL-17RA.

\section{Smoking-induced arthritis aggravation is dependent on AhR activation}

We then investigated the mechanism by which smoking induces the increase in Th17 development. We observed an increased expression of $A h r$ and Cypla1 (downstream of $A h r$ activation) in the inguinal DLNs of mice during AIA (Fig. 2a). Moreover, elevated levels of Cyp1a1 mRNA were clearly evident in the DLNs of mice under AIA when exposed to cigarette smoke compared to those mice exposed to air alone (Fig. 2b). Since AHR is a key inducer of Th17 and Cypla1 is a downstream transcription factor of $A h r$ these results indicate that smoke exposure is inducing AHR activation during Th17 generation in vivo.

Consistent with this notion, smoking-induced arthritis aggravation and increase in Th17 frequencies in AIA was markedly inhibited when the mice were treated with an AHR antagonist, CH223191 (Fig. 2c and d). Importantly, while WT mice developed exacerbated hyperalgesia, increased neutrophil infiltration and Th17 frequencies when exposed to cigarette smoke during AIA, this aggravation was completely absent in $\mathrm{Ahr}^{-1-}$ mice (Fig. 2e and f). These results therefore demonstrate that smoking-induced arthritis aggravation is dependent on AHR activation and elevation of Th17.

\section{Cigarette smoke and polycyclic aromatic hydrocarbons have direct effects on Th17 differentiation and arthritis aggravation}

Using a reporter cell line for AHR ligands (Hepa1-6 pGL4.43), we observed that CSEM induces a concentration-dependent activation of AHR (Fig. 3a). This CSEM was able to increase in vitro differentiation of Th17 cells (Fig. 3b and c), which was abolished by the AHR antagonist CH223191 (Fig. 3b and c). These data suggest a strong link between direct influences of AHR activation in Th17 cells.

We then investigated whether $\mathrm{PAH}$ present in cigarette smoke could modulate Th17 differentiation and exacerbate arthritis. As a PAH prototype we used benzo[b]fluoranthen (BFA), which is found in high concentrations in cigarette smoke [29] and exhibits a potent AHR agonist activity (Fig. 3d). BFA induced an increase in Th17 differentiation in vitro to a similar level as that induced by the AhR endogenous agonist, FICZ, or CSEM (Fig. 3e and f). In vivo, BFA and FICZ also induced arthritis aggravation and an increase of the frequency of Th17 in the draining lymph nodes of AIA mice (Fig. 3g).

Together, these data demonstrate that environmental pollutants with an AHR agonist activity can increase of Th17 cell development and mediate diseases aggravation.

\section{AHR activation in CD4 T cells induces arthritis aggravation and is IL-17A-dependent}

Similar to what was observed for AIA mice exposed to cigarette smoke (Fig. 1e), the AHR agonist FICZ failed to induce arthritis aggravation of AIA in $\mathrm{Il17ra}^{-/-}$mice (Fig. 4a). Furthermore, the disease-exacerbating effect of FICZ was also abolished by the treatment with a neutralizing anti-IL-17 antibody (Fig. 4b). To investigate whether the disease-exacerbating effects of AHR activation on increased articular inflammation was $\mathrm{CD}^{+} \mathrm{T}$ cell-dependent, we performed AIA in chimeric mice. Purified WT CD4 ${ }^{+}$T cells were adoptively transferred into $A h r^{-/-}$mice 1 day before first immunization. $A h r^{-/-}$ 


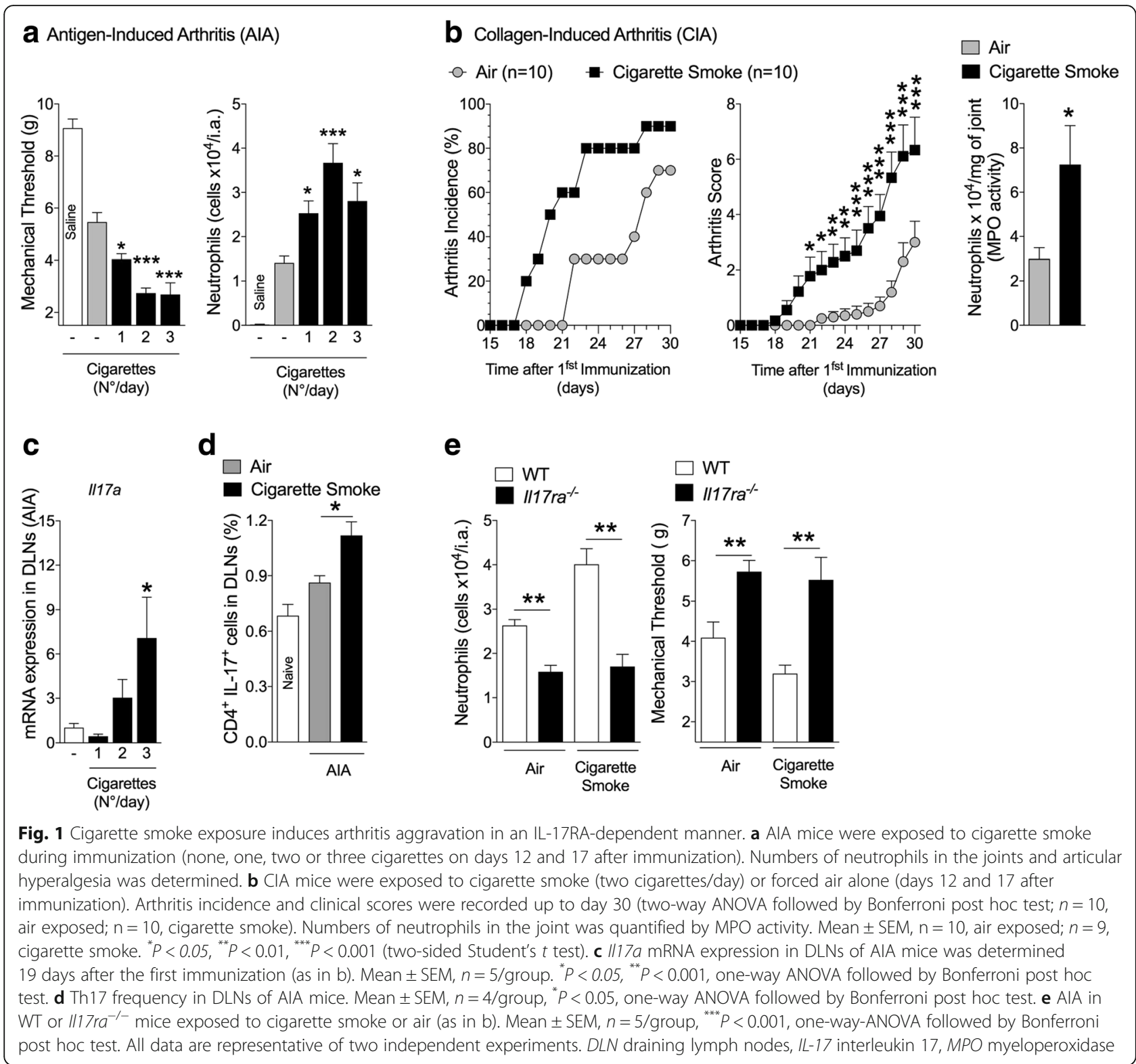

mice were not responsive to FICZ in terms of neutrophil infiltration in the joints, articular hyperalgesia, nor increase in Th17 cell frequency in the DLNs (Fig. 4c). In contrast, these responses were completely restored by the adoptive transfer of $\mathrm{CD}_{4}^{+} \mathrm{T}$ cells from WT mice (Fig. 4c). These results therefore indicate that a direct activation on $\mathrm{CD}^{+}{ }^{+} \mathrm{T}$ cells via Th17 development in vivo is sufficient for the AHR-dependent aggravation of articular inflammatory disease.

\section{Discussion}

Data presented here demonstrate that cigarette smoking-induced aggravation of arthritis is dependent on the activation of AHR and the subsequent induction of Th17 and production of IL-17A. Our study therefore provides a hitherto unrecognized direct linear link among the key players: cigarette smoking and polycyclic aromatic hydrocarbon, AHR activation, IL-17A production, and articular inflammation. The transcriptional mechanism by which AhR regulates Th17 cell differentiation and expansion is not fully understood. Since forced expression of AhR did not impact on Rorc expression in Th17 cells [18] other mechanisms might be involved in the regulation of Th17 development. Analysis of the $I l 17$ loci revealed a putative binding site for AhR on an Ebox element at the $I l 17$ promoter, suggesting that AhR might directly regulate IL-17 expression [30]. Moreover, AHR might also regulate Th17 cell proliferation by the transcriptional control of miR-132/212 clusters, which are important for Th17 development [31]. 


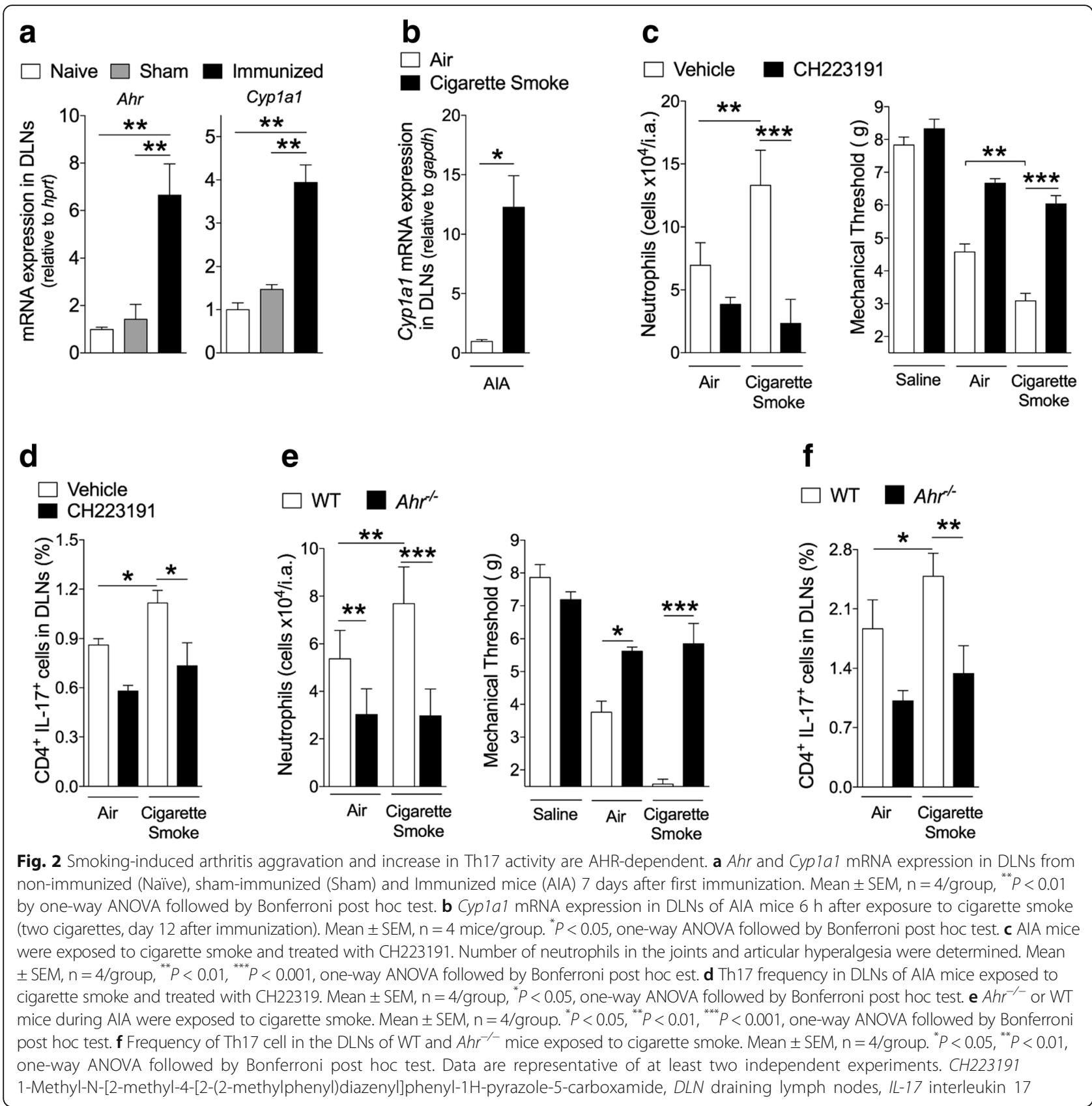

In humans, the activation of AhR in Th17 cells might play a distinct and additive pro-inflammatory role for RA aggravation (e.g. free radicals induction of oxidative stress, induction of peptidyl arginine deiminases) [6-12]. Moreover, although other cell types (e.g. ILC3 and $\gamma \delta$ T cells) are also sources of IL-17 during inflammatory process [32], our data from adoptive transfer experiments suggest that $\mathrm{CD} 4 \mathrm{~T}$ cells are the main target responsible for arthritis aggravation induced by AhR activation. This is consistent with an earlier report showing that AHR in CD4 T cells, but not in other immune cells, is important for arthritis development and Th17 expansion [19]. Our study not only corroborates the previous findings of an AhR cell autonomous role in CD4 T cells for arthritis development, but identify that the major environmental risk for RA development, cigarette smoking, induces disease aggravation through an AhR-dependent increase in Th17 cell response.

It is worth mentioning that several putative AhR agonists have been described to have immunosuppressive activity (e.g. TCDD, Tetrandine, Simomenine) [17, 33-36]. Some of these ligands, including the dioxin 2,3,7,8-Tetrachlorodibenzodioxin (TCDD), have been described as being able to increase Th17 differentiation [37] as well as 


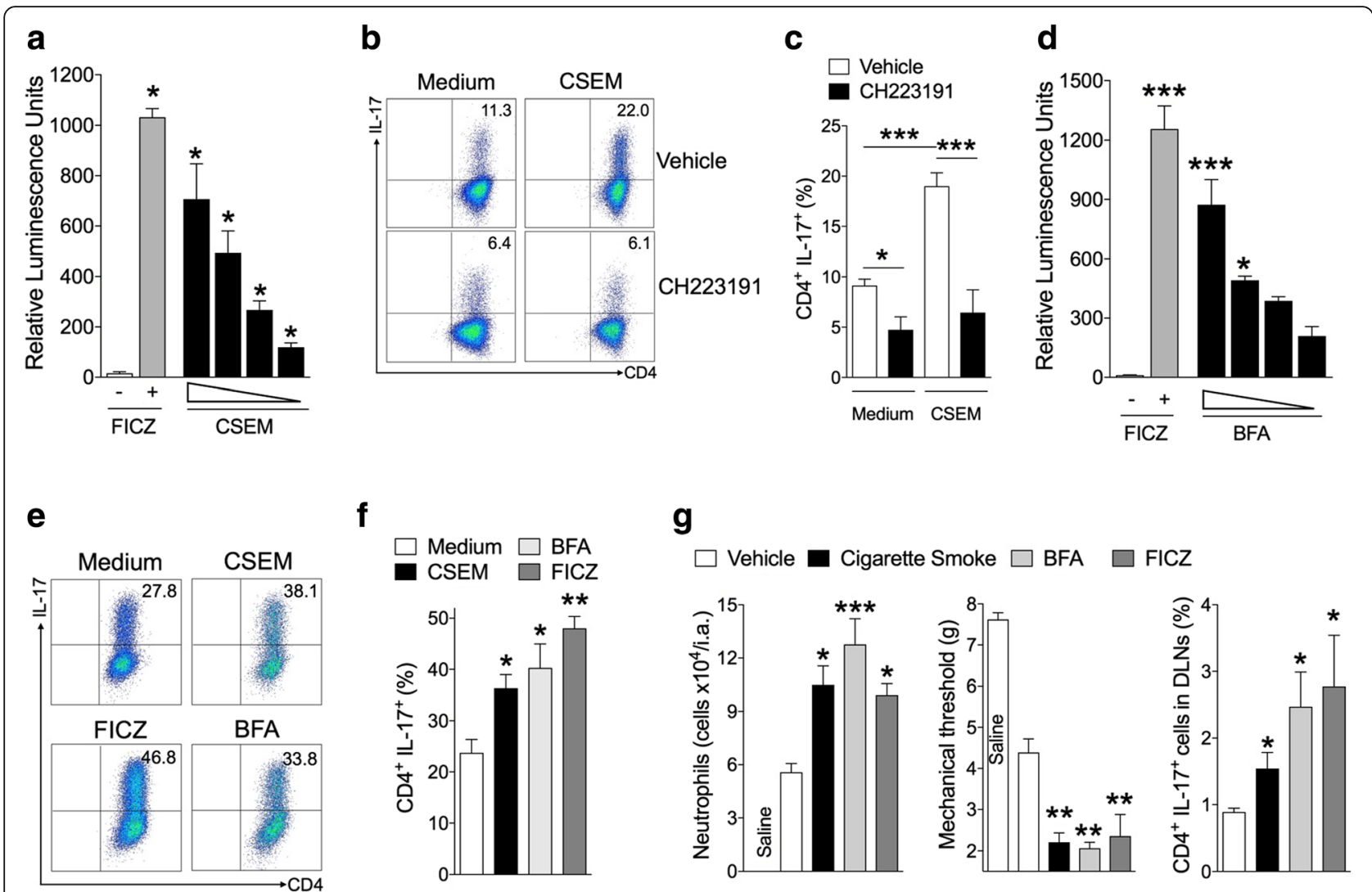

Fig. 3 Cigarette smoke and polycyclic aromatic hydrocarbons affect Th17 differentiation and arthritis aggravation. a RLU (relative luminescence unit) in Hepa1-6.pGL4.43 cells induced by FICZ (300 nM) or cigarette smoke-enriched medium (CSEM: 5, 0.5, 0.05, 0.005 cigarettes/L). Mean \pm SEM, $n=3,{ }^{*} P<0.05$, one-way ANOVA followed by Bonferroni post hoc test. $\mathbf{b}$ and $\mathbf{c}$ Naive CD4 ${ }^{+} \mathrm{T}$ cells from C57BL/6 mice were polarized under Th17 conditions under control medium or CSEM (five cigarettes/L) \pm AHR antagonist (CH223191, $30 \mu M$ ). (d) RLU in Hepa1-6.pGL4.43 cells induced by FICZ (200 nM) or benzo(b)fluoranthene (BFA: 200, 20, 2 and $0.2 \mathrm{nM}$ ). Data are mean $\pm \mathrm{SEM}, \mathrm{n}=3,{ }^{*} P<0.05$ and ${ }^{* * *} P<0.001$ by one-way ANOVA followed by Bonferroni post hoc test. e and $\mathbf{f}$ Naive CD4 ${ }^{+} T$ cells were polarized under Th17 conditions in the presence of BFA (200 nM), FICZ (200 nM) or CSEM (five cigarettes/L). Mean \pm SEM $, n=3,{ }^{*} P<0.05,{ }^{* *} P<0.01$, one-way ANOVA followed by Bonferroni post hoc test. $\mathbf{g}$ AIA mice were exposed to cigarette smoke (two cigarettes) or treated with BFA $(100 \mu \mathrm{g} / \mathrm{kg})$ or FICZ $(90 \mu \mathrm{g} / \mathrm{kg})$. Number of neutrophils in the joints, articular hyperalgesia and Th17 cells in DLNs. Mean \pm SEM, $n=5 /$ group, ${ }^{*} P<0.05,{ }^{* *} P<0.01,{ }^{* * *} P<0.001$, one-way ANOVA followed by Bonferroni post hoc test. Data are representative of two to three independent experiments. BFA benzo[b]fluoranthen, CH223191 1-Methyl-N-[2-methyl-4-[2-(2-methylphenyl)diazenyl]phenyl-1H-pyrazole-5-carboxamide, CSEM cigarette smoke-enriched medium, DLN draining lymph nodes, FICZ 6-formylindolo[3,2-b]carbazole, IL-17 interleukin 17

increase the generation of regulatory $\mathrm{T}$ cells $[17,37]$. In our experiments, the role of AhR on smoking-induced arthritis aggravation is demonstrated by the lack of smoking effects on mice genetically deficient to AhR. Moreover, the AhR antagonist $\mathrm{CH} 223191$ also reduced smokinginduced arthritis aggravation, suggesting blockage of this receptor could be an important target for RA management. The genetic evidence describing that AhR plays a major role on Th17 differentiation [18, 37], and the AhRindependent activity of dioxins [38], suggest that some of the immunosuppressive effects observed could be dependent of unknown biologic targets of AhR ligands.

In this study, we also identified that PAHs can also induce arthritis aggravation by modulation of Th17 generation in vivo and in vitro. It would be of considerable importance to analyze the active PAHs of cigarette smoke associated with the exacerbation of RA as several AHR ligands have been identified in cigarette smoke [39-41]. Moreover, PAHs and other putative AhR agonists might not only increase AhR activity by direct binding to this receptor, but also by inhibition of oxidases that degrade the endogenous ligands of AhR [42], which increase the group of compounds that could affect the described AhR-Th17 relationship.

Given the promiscuous nature of AHR binding, other environmental risk factors linked to RA by epidemiologic evidence are likely to be sources of AHR ligands and could be related to disease development [21, 41, 43-46]. One example is the intriguing association of living proximity to heavy traffic, exposure to traffic pollution, and RA development [47]. In our experiments, a brief exposure to cigarette smoke and AhR activation can induce 

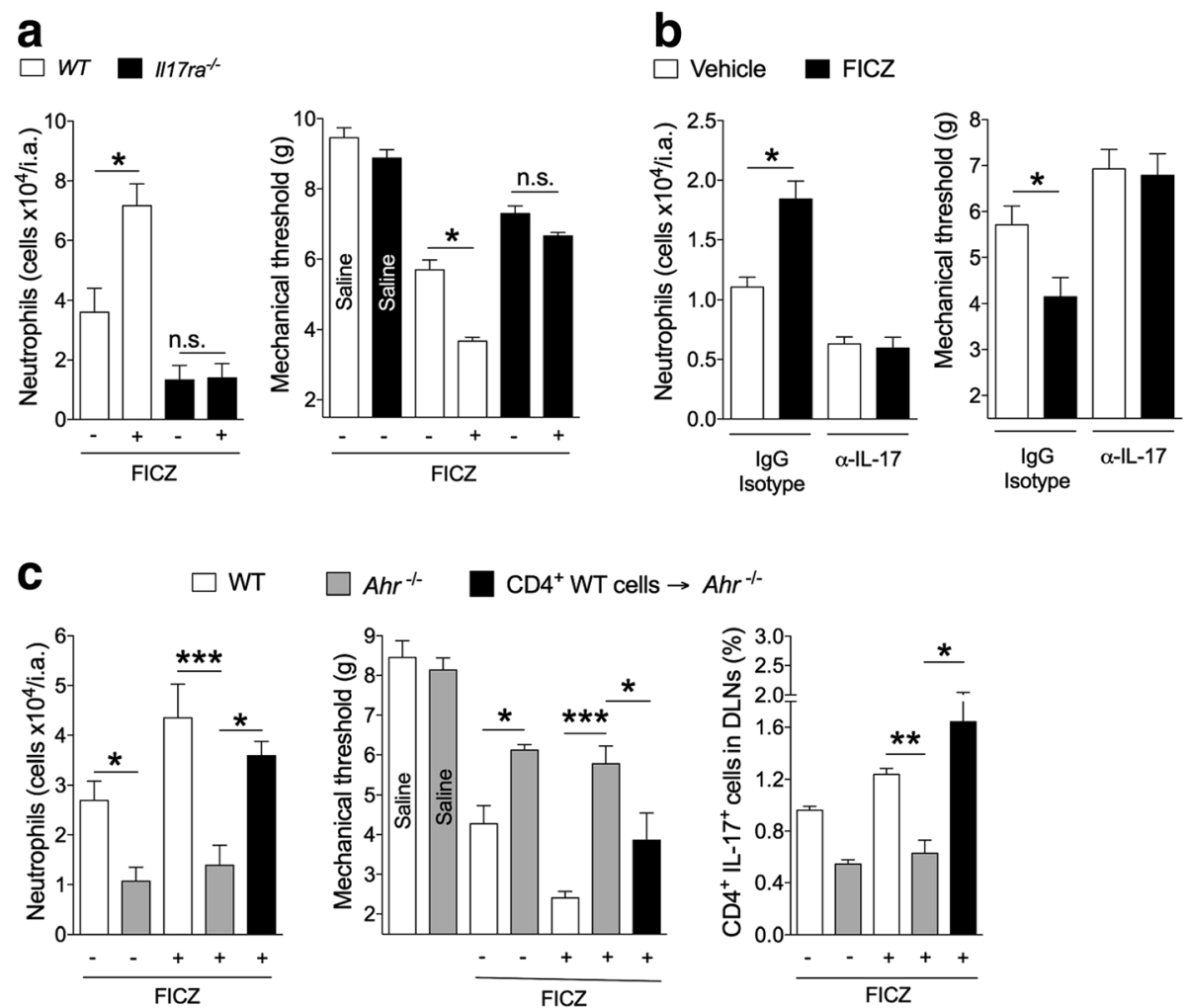

Fig. 4 AHR activation in T cells induces arthritis aggravation in an IL-17RA-dependent manner. a AIA was induced in WT or $/ 117 \mathrm{ra}^{-1-}$ mice and treated with vehicle or FICZ $(90 \mathrm{\mu g} / \mathrm{kg})$ during immunization. Neutrophil in the joints and hyperalgesia were determined $7 \mathrm{~h}$ after challenge. Mean \pm SEM, $n=5 /$ group, ${ }^{*} P<0.05$; n.S, not significant, one-way ANOVA followed by Bonferroni post hoc test. $\mathbf{b}$ AIA was induced in WT mice treated with anti-lL-17 (a-IL-17) or the isotype control antibody at the same time as the mice were treated with vehicle or FICZ. Neutrophil in the joints and hyperalgesia were determined $7 \mathrm{~h}$ after challenge. Mean \pm SEM, $n=5 /$ group, ${ }^{*} P<0.05 ; n$.s, not significant, one-way ANOVA followed by Bonferroni post hoc test. c AIA was induced in WT or Ahr ${ }^{-1-}$ mice. The mice were treated or not with FICZ. One group of Ahr ${ }^{-1-}$ mice $\left(C D 4^{+} W T\right.$ cells $\rightarrow \mathrm{Ahr}^{-1-}$ ) received $\mathrm{CD} 4{ }^{+}$T cells from $W T$ mice 1 day before the first immunization. Data are mean $\pm \mathrm{SEM}, \mathrm{n}=5 /$ group $,{ }^{*} P<0.05,{ }^{* *} P<0.01$, ${ }^{* * *} P<0.001$, one-way ANOVA followed by Bonferroni post hoc test. All data are representative of two independent experiments. DLN draining lymph nodes, FICZ 6-formylindolo[3,2-b]carbazole, IL-17 interleukin 17

aggravation of arthritis, while in humans the timeline for duration of cigarette smoke exposure and RA development might be longer. However, epidemiologic evidence suggests that even low exposure during the lifetime to cigarette smoking increases the risk for RA [48]. In humans, several factors account for the break of selftolerance and RA development (e.g. specific microbiota, genetic background). In our proposed model, cigarette smoke exposure might potentiate the events that lead to disease development and aggravation.

\section{Conclusions}

This study shows that smoking-induced arthritis aggravation is dependent on AhR activation in Th17 cells and IL-17Ra signaling. Given the pervasive pathogenic nature of Th17 cells, our findings may also extend to other diseases such as inflammatory bowel disease [49-51], atherosclerosis [52, 53], cancer [54, 55] and periodontitis $[56,57]$ all of which have a strong link to smoking.

\section{Abbreviations}

AHR: Aryl hydrocarbon receptor; AIA: Antigen-induced arthritis; BFA: Benzo[b]fluoranthen; CFA: Complete Freund's adjuvant; $\mathrm{CH} 223191$ : 1Methyl-N-[2-methyl-4-[2-(2-methylphenyl)diazenyl] phenyl-1H-pyrazole-5carboxamide; CIA: Collagen-induced arthritis; CSEM: Cigarette smokeenriched medium; DLN: Draining lymph nodes; DMSO: Dimethyl sulfoxide; FICZ: 6-formylindolo[3,2-b]carbazole; IFA: Incomplete Freund's adjuvant; IL17: Interleukin 17; IL-17Ra: Interleukin 17 receptor A; mBSA: Methylated bovine serum albumin; MPO: Myeloperoxidase; PAH: Polycyclic aromatic hydrocarbons; PBS: Phosphate-buffered saline; PMA: Phorbol-12-myristate-13acetate; RA: Rheumatoid arthritis

\section{Acknowledgements}

We thank Valerie Quesniaux, Isabelle Maillet, Nathalie Froux, Pascale Mauny and members of UMR7355, INEM at CNRS Orleans for support and technical assistance in the Ahr $r^{-1}$ AlA experiments. The authors also would like to thank Giuliana B. Francisco, Sergio R. Rosa, Katia Santos and leda Schivo for technical assistance.

\section{Funding}

The research leading to these results received funding from the European Union Seventh Framework Programme [FP7-2007-2013] under grant agreement number HEALTH-F4-2011-281608 (TIMER), from the São Paulo Research Foundation (FAPESP) under grant agreements number 2011/19670-0 (Projeto Temático) and 2013/08216-2 (Center for Research in Inflammatory 
Disease) and from the University of São Paulo NAP-DIN under grant agreement number 11.1.21625.01.0.

\section{Availability of data and materials}

Data sharing not applicable to this article as no datasets were generated or analysed during the current study.

\section{Authors' contributions}

JT, FQC, PLJ and FYL conceived, designed the study and analyzed data. JT, $P L J, F Y L, B R$ and FQC planned experiment. JT performed in vitro and in vivo experiments. RSP, LGP, JRS, BR, KAL and PBD contributed to perform in vivo experiments. KAL and PBD contributed to performed in vitro experiments. $B R, F Y L, R D R O, T M C$ and JCAF provided essential materials and contributed to the study's conception and revised the manuscript. JT, FQC, PLJ and FYL drafted the manuscript. All authors read and approved the final manuscript.

\section{Ethics approval}

The local ethical committee from the Ribeirão Preto Medical School (FMRP) approved the conduct of all experiments involving animal research [Animal Ethics Committee of the School of Medicine of Ribeirao Preto, University of São Paulo (n038/2009)].

\section{Competing interests}

The authors declare that they have no competing interests.

\section{Publisher's Note}

Springer Nature remains neutral with regard to jurisdictional claims in published maps and institutional affiliations.

\section{Author details}

'Department of Pharmacology, Ribeirao Preto Medical School, University of Sao Paulo, Av. Bandeirantes, 3900, Ribeirao Preto, SP 14049900, Brazil. ${ }^{2}$ Department of Immunology, Ribeirao Preto Medical School, University of São Paulo, Ribeirao Preto, Brazil. ${ }^{3}$ Division of Clinical Immunology, Ribeirao Preto Medical School, University of São Paulo, Ribeirao Preto, Brazil. ${ }^{4}$ Université Orleans and Centre National de la Recherche Scientifique, Molecular Immunology, UMR7355, INEM, Orleans, France. ${ }^{5}$ Institute of Infectious Disease and Molecular Medicine, UCT, Cape Town, South Africa. ${ }^{6}$ Division of Immunology, Infection and Inflammation, Glasgow Biomedical Research Centre, University of Glasgow, Glasgow G12 8TA, UK. ${ }^{7}$ School of Biology and Basic Medical Sciences, Soochow University, Suzhou 215006, China.

\section{Received: 24 January 2018 Accepted: 26 April 2018}

\section{Published online: 08 June 2018}

\section{References}

1. Heliovaara M, Aho K, Aromaa A, Knekt P, Reunanen A. Smoking and risk of rheumatoid arthritis. J Rheumatol. 1993;20(11):1830-5.

2. Karlson EW, Lee IM, Cook NR, Manson JE, Buring JE, Hennekens CH. A retrospective cohort study of cigarette smoking and risk of rheumatoid arthritis in female health professionals. Arthritis Rheum. 1999:42(5):910-7.

3. Firestein GS. Evolving concepts of rheumatoid arthritis. Nature. 2003; 423(6937):356-61.

4. Sugiyama D, Nishimura K, Tamaki K, Tsuji G, Nakazawa T, Morinobu A Kumagai S. Impact of smoking as a risk factor for developing rheumatoid arthritis: a meta-analysis of observational studies. Ann Rheum Dis. 2010; 69(1):70-81.

5. Saevarsdottir S, Rezaei H, Geborek P, Petersson I, Ernestam S, Albertsson K, Forslind K, van Vollenhoven RF, SWEFOT study group. Current smoking status is a strong predictor of radiographic progression in early rheumatoid arthritis: results from the SWEFOT trial. Ann Rheum Dis. 2015;74(8):1509-14.

6. Pryor WA, Stone K. Oxidants in cigarette smoke. Radicals, hydrogen peroxide, peroxynitrate, and peroxynitrite. Ann N Y Acad Sci. 1993;686:1227. discussion 27-18

7. Kalpakcioglu B, Senel K. The interrelation of glutathione reductase, catalase, glutathione peroxidase, superoxide dismutase, and glucose-6-phosphate in the pathogenesis of rheumatoid arthritis. Clin Rheumatol. 2008;27(2):141-5.

8. Wegner N, Lundberg K, Kinloch A, Fisher B, Malmstrom V, Feldmann M, Venables PJ. Autoimmunity to specific citrullinated proteins gives the first clues to the etiology of rheumatoid arthritis. Immunol Rev. 2010;233(1):34-54.
9. Klareskog L, Stolt P, Lundberg K, Kallberg H, Bengtsson C, Grunewald J, Ronnelid J, Harris HE, Ulfgren AK, Rantapaa-Dahlqvist S, et al. A new model for an etiology of rheumatoid arthritis: smoking may trigger HLA-DR (shared epitope)-restricted immune reactions to autoantigens modified by citrullination. Arthritis Rheum. 2006;54(1):38-46.

10. Gyorgy B, Toth E, Tarcsa E, Falus A, Buzas El. Citrullination: a posttranslational modification in health and disease. Int J Biochem Cell Biol. 2006;38(10):1662-77.

11. Makrygiannakis D, Hermansson M, Ulfgren AK, Nicholas AP, Zendman AJ, Eklund A, Grunewald J, Skold CM, Klareskog L, Catrina Al. Smoking increases peptidylarginine deiminase 2 enzyme expression in human lungs and increases citrullination in BAL cells. Ann Rheum Dis. 2008;67(10):1488-92.

12. Lee J, Luria A, Rhodes C, Raghu H, Lingampalli N, Sharpe O, Rada B, Sohn $\mathrm{DH}$, Robinson WH, Sokolove J. Nicotine drives neutrophil extracellular traps formation and accelerates collagen-induced arthritis. Rheumatology (Oxford). 2017;56(4):644-53.

13. Wang H, Yu M, Ochani M, Amella CA, Tanovic M, Susarla S, Li JH, Wang H, Yang $\mathrm{H}$, Ulloa $\mathrm{L}$, et al. Nicotinic acetylcholine receptor alpha7 subunit is an essential regulator of inflammation. Nature. 2003;421(6921):384-8.

14. Leipe J, Grunke M, Dechant C, Reindl C, Kerzendorf U, Schulze-Koops H, Skapenko A. Role of Th17 cells in human autoimmune arthritis. Arthritis Rheum. 2010;62(10):2876-85.

15. Gaffen SL. The role of interleukin-17 in the pathogenesis of rheumatoid arthritis. Curr Rheumatol Rep. 2009;11(5):365-70.

16. Ciofani M, Madar A, Galan C, Sellars M, Mace K, Pauli F, Agarwal A, Huang W, Parkhurst CN, Muratet M, et al. A validated regulatory network for Th17 cell specification. Cell. 2012;151(2):289-303.

17. Quintana FJ, Basso AS, Iglesias AH, Korn T, Farez MF, Bettelli E, Caccamo M, Oukka M, Weiner HL. Control of T(reg) and $\mathrm{T}(\mathrm{H}) 17$ cell differentiation by the aryl hydrocarbon receptor. Nature. 2008;453(7191):65-71.

18. Veldhoen M, Hirota K, Westendorf AM, Buer J, Dumoutier L, Renauld JC, Stockinger B. The aryl hydrocarbon receptor links TH17-cell-mediated autoimmunity to environmental toxins. Nature. 2008:453(7191):106-9.

19. Nakahama T, Kimura A, Nguyen NT, Chinen I, Hanieh H, Nohara K, FujiiKuriyama Y, Kishimoto T. Aryl hydrocarbon receptor deficiency in T cells suppresses the development of collagen-induced arthritis. Proc Natl Acad Sci U S A. 2011:108(34):14222-7.

20. Denison MS, Nagy SR. Activation of the aryl hydrocarbon receptor by structurally diverse exogenous and endogenous chemicals. Annu Rev Pharmacol Toxicol. 2003;43:309-34.

21. Stejskalova L, Dvorak Z, Pavek P. Endogenous and exogenous ligands of aryl hydrocarbon receptor: current state of art. Curr Drug Metab. 2011;12(2):198-212.

22. Safe SH. Modulation of gene expression and endocrine response pathways by 2,3,7,8-tetrachlorodibenzo-p-dioxin and related compounds. Pharmacol Ther. 1995;67(2):247-81.

23. Ye P, Rodriguez FH, Kanaly S, Stocking KL, Schurr J, Schwarzenberger P, Oliver P, Huang W, Zhang P, Zhang J, et al. Requirement of interleukin 17 receptor signaling for lung CXC chemokine and granulocyte colonystimulating factor expression, neutrophil recruitment, and host defense. J Exp Med. 2001;194(4):519-27.

24. Fernandez-Salguero P, Pineau T, Hilbert DM, McPhail T, Lee SS, Kimura S, Nebert DW, Rudikoff S, Ward JM, Gonzalez FJ. Immune system impairment and hepatic fibrosis in mice lacking the dioxin-binding Ah receptor. Science. 1995:268(5211):722-6.

25. Brand DD, Latham KA, Rosloniec EF. Collagen-induced arthritis. Nat Protoc. 2007:2(5):1269-75.

26. Shan $M$, Yuan $X$, Song $L Z$, Roberts L, Zarinkamar N, Seryshev A, Zhang $Y$, Hilsenbeck S, Chang SH, Dong C, et al. Cigarette smoke induction of osteopontin (SPP1) mediates $T(H) 17$ inflammation in human and experimental emphysema. Sci Transl Med. 2012:4(117):117ra119.

27. Pinto LG, Cunha TM, Vieira SM, Lemos HP, Verri WA Jr, Cunha FQ, Ferreira SH. IL-17 mediates articular hypernociception in antigen-induced arthritis in mice. Pain. 2010;148(2):247-56.

28. Cunha TM, Dal-Secco D, Verri WA Jr, Guerrero AT, Souza GR, Vieira SM, Lotufo CM Neto AF, Ferreira SH, Cunha FQ. Dual role of hydrogen sulfide in mechanical inflammatory hypernociception. Eur J Pharmacol. 2008;590(1-3):127-35.

29. Lodovici M, Akpan V, Evangelisti C, Dolara P. Sidestream tobacco smoke as the main predictor of exposure to polycyclic aromatic hydrocarbons. J Appl Toxicol. 2004;24(4):277-81.

30. Cui G, Qin X, Wu L, Zhang Y, Sheng X, Yu Q, Sheng H, Xi B, Zhang JZ, Zang $Y Q$. Liver $X$ receptor (LXR) mediates negative regulation of mouse and human Th17 differentiation. J Clin Invest. 2011;121(2):658-70. 
31. Nakahama T, Hanieh $H$, Nguyen NT, Chinen I, Ripley B, Millrine D, Lee S, Nyati KK, Dubey PK, Chowdhury K, et al. Aryl hydrocarbon receptormediated induction of the microRNA-132/212 cluster promotes interleukin17-producing T-helper cell differentiation. Proc Natl Acad Sci U S A. 2013; 110(29):11964-9.

32. Cua DJ, Tato CM. Innate IL-17-producing cells: the sentinels of the immune system. Nat Rev Immunol. 2010;10(7):479-89.

33. Yuan $X$, Dou $Y$, Wu X, Wei Z, Dai $Y$. Tetrandrine, an agonist of aryl hydrocarbon receptor, reciprocally modulates the activities of STAT3 and STAT5 to suppress Th17 cell differentiation. J Cell Mol Med. 2017;21(9):2172-83.

34. Tong B, Yuan X, Dou Y, Wu X, Wang Y, Xia Y, Dai Y. Sinomenine induces the generation of intestinal Treg cells and attenuates arthritis via activation of aryl hydrocarbon receptor. Lab Investig. 2016;96(10):1076-86.

35. Tong B, Yuan X, Dou Y, Wu X, Chou G, Wang Z, Xia Y, Dai Y. Norisoboldine, an isoquinoline alkaloid, acts as an aryl hydrocarbon receptor ligand to induce intestinal Treg cells and thereby attenuate arthritis. Int J Biochem Cell Biol. 2016;75:63-73.

36. Yuan X, Tong B, Dou Y, Wu X, Wei Z, Dai Y. Tetrandrine ameliorates collagen-induced arthritis in mice by restoring the balance between Th17 and Treg cells via the aryl hydrocarbon receptor. Biochem Pharmacol. 2016; 101:87-99.

37. Kimura A, Naka T, Nohara K, Fujii-Kuriyama Y, Kishimoto T. Aryl hydrocarbon receptor regulates Stat1 activation and participates in the development of Th17 cells. Proc Natl Acad Sci U S A. 2008;105(28):9721-6.

38. Lee YC, Oslund KL, Thai P, Velichko S, Fujisawa T, Duong T, Denison MS, Wu R. 2,3,7,8-Tetrachlorodibenzo-p-dioxin-induced MUC5AC expression: aryl hydrocarbon receptor-independent/EGFR/ERK/p38-dependent SP1-based transcription. Am J Respir Cell Mol Biol. 2011;45(2):270-6.

39. Baka Z, Buzás E, Nagy G. Rheumatoid arthritis and smoking: putting the pieces together. Arthritis Res Ther. 2009;11(4):238.

40. Saevarsdottir S, Rezaei H, Geborek P, Petersson I, Ernestam S, Albertsson K, Forslind $\mathrm{K}$, van Vollenhoven RF, SWEFOT study group. Current smoking status is a strong predictor of radiographic progression in early rheumatoid arthritis: results from the SWEFOT trial. Ann Rheum Dis. 2014;0:1-6.

41. Klareskog L, Catrina Al, Paget S. Rheumatoid arthritis. Lancet. 2009; 373(9664):659-72

42. Schiering C, Vonk A, Das S, Stockinger B, Wincent E. Cytochrome P4501inhibiting chemicals amplify aryl hydrocarbon receptor activation and IL-22 production in T helper 17 cells. Biochem Pharmacol. 2018;151:47-58.

43. Stolt P, Bengtsson C, Nordmark B, Lindblad S, Lundberg I, Klareskog L, Alfredsson L. Quantification of the influence of cigarette smoking on rheumatoid arthritis: results from a population based case-control study, using incident cases. Ann Rheum Dis. 2003;62(9):835-41.

44. Saevarsdottir S, Wedren S, Seddighzadeh M, Bengtsson C, Wesley A, Lindblad S, Askling J, Alfredsson L, Klareskog L. Patients with early rheumatoid arthritis who smoke are less likely to respond to treatment with methotrexate and tumor necrosis factor inhibitors: observations from the Epidemiological Investigation of Rheumatoid Arthritis and the Swedish Rheumatology Register cohorts. Arthritis Rheum. 2011;63(1):26-36.

45. Hellgren $\mathrm{L}$. The prevalence of rheumatoid arthritis in occupational groups. Scand J Rheumatol. 1987;16(1):106-13.

46. Lundberg I, Alfredsson L, Plato N, Sverdrup B, Klareskog L, Kleinau S. Occupation, occupational exposure to chemicals and rheumatological disease: a register based cohort study. Scand J Rheumatol. 1994;23(6):305-10.

47. Hart JE, Laden F, Puett RC, Costenbader KH, Karlson EW. Exposure to traffic pollution and increased risk of rheumatoid arthritis. Environ Health Perspect. 2009;117(7):1065-9.

48. Di Giuseppe D, Discacciati A, Orsini N, Wolk A. Cigarette smoking and risk of rheumatoid arthritis: a dose-response meta-analysis. Arthritis Res Ther. 2014; 16(2):R61.

49. Mahid SS, Minor KS, Soto RE, Hornung CA, Galandiuk S. Smoking and inflammatory bowel disease: a meta-analysis. Mayo Clin Proc. 2006; 81(11):1462-71.

50. Hundorfean G, Neurath MF, Mudter J. Functional relevance of T helper 17 (Th17) cells and the IL-17 cytokine family in inflammatory bowel disease. Inflamm Bowel Dis. 2012;18(1):180-6.

51. Monteleone I, Pallone F, Monteleone G. Aryl hydrocarbon receptor and colitis. Semin Immunopathol. 2013;35(6):671-5.

52. Potekhina AV, Pylaeva E, Provatorov S, Ruleva N, Masenko V, Noeva E, Krasnikova T, Arefieva T. Treg/Th17 balance in stable CAD patients with different stages of coronary atherosclerosis. Atherosclerosis. 2015;238(1):17-21.
53. Howard G, Wagenknecht LE, Burke GL, Diez-Roux A, Evans GW, McGovern P, Nieto FJ, Tell GS. Cigarette smoking and progression of atherosclerosis: The Atherosclerosis Risk in Communities (ARIC) Study. JAMA. 1998;279(2):119-24.

54. Duan MC, Zhong XN, Liu GN, Wei JR. The Treg/Th17 paradigm in lung cancer. J Immunol Res. 2014;2014:730380.

55. Carter BD, Abnet CC, Feskanich D, Freedman ND, Hartge P, Lewis CE, Ockene JK, Prentice RL, Speizer FE, Thun MJ, et al. Smoking and mortalitybeyond established causes. N Engl J Med. 2015;372(7):631-40.

56. Bergstrom J. Tobacco smoking and chronic destructive periodontal disease. Odontology. 2004;92(1):1-8.

57. Cheng WC, Hughes FJ, Taams LS. The presence, function and regulation of IL-17 and Th17 cells in periodontitis. J Clin Periodontol. 2014;41(6):541-9.

\section{Ready to submit your research? Choose BMC and benefit from:}

- fast, convenient online submission

- thorough peer review by experienced researchers in your field

- rapid publication on acceptance

- support for research data, including large and complex data types

- gold Open Access which fosters wider collaboration and increased citations

- maximum visibility for your research: over $100 \mathrm{M}$ website views per year

At BMC, research is always in progress.

Learn more biomedcentral.com/submissions 